\title{
Liner shipping alliances and their \\ impact on shipping connectivity in Southeast Asia
}

Wei Yim Yap and Seyed Mehdi Zahraei
Business, Singapore University of Social Sciences, Singapore

Wei Yim Yap and Seyed Mehdi Zahraei
School of Business, Singapore University of Social Sciences, Singapore

Liner shipping

alliances

\begin{abstract}
Purpose - The liner shipping industry underwent a major round of change between 2014 and 2017 where the concentration ratio of the top ten carriers rose from 64 per cent in 2013 to 82 per cent by 2017. This paper aims to analyze the impact of these developments on the state of shipping connectivity for major container transshipment hubs in Southeast Asia, namely, Port Klang, Singapore and Tanjung Pelepas.

Design/methodology/approach - The developments in shipping services deployed before and after the latest round of reshuffling in the liner shipping industry were analyzed.

Findings - Significant service rationalization took place in the period that saw 38 per cent reduction in the number of shipping services called at the ports. Participation in alliance arrangement was revealed to be important for shipping lines to compete successfully on the Asia-Europe trade route in the new shipping landscape. Terminal operators should expect further rationalization of services should overcapacity persist. Maintaining hub status would require the ability to accommodate the strategic, operational and commercial requirements of the entire alliance rather than just focusing on the key shipping line.

Originality/value - This is the first paper to examine the effects of the latest round of consolidation in the liner shipping industry. In-depth analyses were conducted for shipping services where the service configuration was examined. The case of Southeast Asia and the Asia-Europe trade route was used to illustrate the impact with managerial and policy implications for shipping lines, terminal operators and port authorities.
\end{abstract}

Keywords Southeast Asia, Shipping alliance, Asia-Europe trade, Shipping connectivity

Paper type Research paper

\section{Introduction}

The liner shipping industry underwent a major round of shuffle between 2014 and 2017. The period saw the dissolution of the G6 Alliance and CHKYE Alliance as a result of the bankruptcy of Hanjin as well as mergers and acquisitions involving container shipping lines Maersk, CMA CGM, COSCO, China Shipping, OOCL, APL, Hamburg-Süd, CSAV, CCNI and UASC. The result was the formation of three shipping alliances which are the $2 \mathrm{M}$ alliance, Ocean Alliance and The Alliance. These developments affected more than 80 per cent of the global container fleet capacity with fourteen out of the top fifteen container shipping lines belonging to an alliance. The concentration ratio of the top ten carriers increased further from 64 per cent in 2013 to reach 82 per cent by 2017 (Alphaliner, 2013, 2017a). A list of events detailing container shipping lines affected is shown in Table I.

The Asia-Europe trade is a major east-west container trade. Container traffic on the trade route is estimated at 23 million TEUs in 2017 (UNCTAD, 2017). The trade route connects major load centers of East Asia with that of Europe and the Mediterranean region. Shipping lines that ply along the trade route also call at key ports in Southeast Asia, South

(C) Pacific Star Group Education Foundation. Licensed re-use rights only. 


\section{MABR \\ 3,3}

Jul (1)

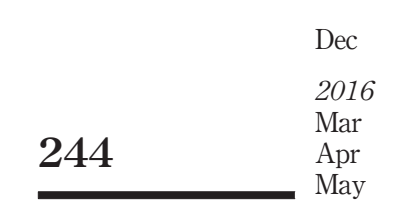

Jun

Aug

Dec

2017

Feb

Table I. May

Carriers involved in Aug

alliance reshuffle, mergers and acquisitions from 2014 to 2017

Jul
2M alliance formed consisting of Maersk and MSC

Hapag-Lloyd acquires CCNI

Hapag-Lloyd acquires CSAV

COSCO and China Shipping merge to form China Cosco Shipping Corporation (COSCO)

Ocean Alliance formed, consisting of CMA CGM, COSCO, Evergreen and OOCL

The Alliance formed, consisting of Hapag-Lloyd, K Line, MOL, NYK and Yang Ming; G6 and CHKYE dissolved

CMA CGM acquires APL

Hanjin files for receivership

ZIM tie-up with The Alliance

Hyundai tie-up with $2 \mathrm{M}$ alliance

Source: Authors, compiled from various sources including Zhong (2014), Power et al. (2016), Espina (2016), Knowler (2016), Lakshmi (2016), Wackett (2016), Reuters (2016a, 2016b), The Straits Times (2017a) and Saadi (2017)

Asia and the Middle East. It is worth noting that the eighteen busiest container ports in the world are located along the Asia-Europe trade route. Of these, the ports of Singapore, Port Klang and Tanjung Pelepas were ranked 2nd, 12th and 18th, respectively, in 2015 where they accounted for almost 100 per cent of Southeast Asia's transshipment throughput (Lam and Yap, 2008). The Asia-Europe trade is also an important market for transshipment traffic for the ports of Singapore, Port Klang and Tanjung Pelepas (Yap and Notteboom, 2011). In 2015, the three ports handled 51.6 million TEUs of containers (American Association of Port Authorities, 2017). Of this amount, 80.6 per cent or 41.6 million TEUs consisted of transshipment containers thereby presenting the region as one of the largest container transshipment markets in the world.

Southeast Asia is a major transshipment market in the world with all three shipping alliances having well-developed shipping service connectivity in the ports of Singapore, Port Klang and Tanjung Pelepas (Lam and Yap, 2008). However, the literature has not adequately addressed the issue of connectivity from the perspective of relationships between two ports. This will require investigation into the direction of ship routing as well as frequency of calls for the set of ports involved. Furthermore, network reorganization as a result of consolidation and changes in alliance memberships will trigger new dynamics in the container shipping scene. In view of the aforementioned events which took place in the liner industry, they warrant investigation into the impact these developments have on the container shipping and port landscape. As such, the paper aims to examine the impact of recent developments in alliance membership over the period from 2013 to 2017 on liner connectivity for each of these major container hubs for the Asia-Europe trade route. The paper is organized as follows. In the next section, we cover research efforts devoted to this subject. Section three presents the research methodology. In section four, we discuss the results of our analysis and implications from the managerial and policy perspectives. Section five concludes with recommendations for future research. 


\section{Literature review}

Shipping lines engage in alliances to reap perceived strategic, commercial and operational objectives in a bid to gain an advantage over rival companies. Ryoo and Lee (2002) suggested that cooperative behavior could enhance network reach and frequency of connections compared to competing carriers. The capital intensive and highly competitive nature of container shipping line operations has resulted in a few shipping lines dominating the market (Chao, 2017). Lam (2013) observed from a supply chain perspective that shipping lines integrate their fleet capacity to realize economies linked to a larger cargo volume and lower unit cost of operation. The benefits of shipping alliances also included enhanced operational synergy and efficiency through the form of slot sharing and joint services (Evangelista and Morvillo, 1999; Ryoo and Thanopoulou, 1999), and Slack et al. (2002) noted that wider markets could be accessed through shipping alliances. Wen (2012) also observed that collaborative arrangements served to boost logistics capability and competitive advantage of shipping lines.

Nonetheless, container shipping alliances were found to be inherently unstable having seen structural changes over the years (Das, 2011). Rau and Spinler (2017) observed that the intensity of competition, cost of complexity of the alliance and volatility in freight rate led to alliance instability. Ferrari et al. (2008) highlighted that optimizing shipping networks could aid the success of shipping alliances, and Midoro and Pitto (2000) pointed out that stability and efficiency of shipping alliances could be strengthened with fewer partners with clear differentiating of roles and contributions, and through coordinating marketing and sales. Yang et al. (2011) also observed that the strategy of jointly using mega ships focusing on lowering unit costs for members would aid alliance stability.

On the issue of connectivity, shipping networks offer a practical avenue to determine, quantify and evaluate connectivity based on their origin-destination pairings of specific port nodes. A formal approach to capture parameters associated with connectivity was developed by Tang et al. (2011) which included trade volume, cargo traffic, port calls, port draft, port charges, turnaround time, operating hours and the factor of intermodal transport. Calatayud et al. (2017) emphasized that connectivity should be investigated and measured in relation to alternative routings that are deemed relevant in view of the dynamic nature of global trade movements and the way of response by shipping lines. These effects would determine the position of a port in the context of shipping networks and thereby reveal its connectivity. However, Lam and Yap (2011) found that establishing the presence of connectivity between two ports is not sufficient because it does not reveal the relationship between these ports. The relationship could be one of intense competition or complementarity depending on the nature of the trade network where the ports are intended to serve. Yap and Lam (2013) further highlighted that shipping connectivity is an important issue for countries that rely on shipping networks for direct market access to international trade. Toward this purpose, container ports that serve these countries would be required to have the necessary facilities to accommodate the shipping networks and associated shipping capacity.

The latest developments in the container shipping industry are unprecedented in their scales which affected all the major container trades involving more than 80 per cent of global container fleet capacity (Alphaliner, 2017a). The impact on connectivity as a result of these developments has not been addressed in the literature. As such, this paper attempts to investigate the impact of these developments in the context of the Asia-Europe trade route with a focus on the three container transshipment hubs in Southeast Asia. The investigation will also research into the dynamics of port competition and port complementarity between these ports through developments in shipping connectivity that are provided by shipping
Liner shipping alliances 
MABR

3,3

\section{6}

Figure 1.

Categorization and analysis of shipping services calling at Singapore, Port Klang and Tanjung Pelepas on the AsiaEurope trade route networks. The research will also attempt to shed light on important implications from the perspective of contestability, terminal investments and capacity development for port managers and policy makers.

\section{Research methodology}

The focus of the research is on the Asia-Europe container trade and the geographical region of Southeast Asia. Container ports selected for our research are the ports of Port Klang, Singapore and Tanjung Pelepas. We begin from the perspective that container shipping services that operate on the Asia-Europe trade route might be deployed to call at different ports, have different order of calls among the three ports and be alliance or non-alliance members. We use $k_{z, q}^{m}$ to distinguish container shipping services with these different characteristics, where $z$ determines if service $k$ operates under the aegis of any shipping alliances, $q$ denotes the order of calls by service $k$ and $m$ denotes the arrangements of the port-calls by service $k . m, q$ and $z$ values are determined as follows:

$$
\begin{aligned}
& z= \begin{cases}0 & \text { non - alliance member } \\
1 & \text { alliance member }\end{cases} \\
& q= \begin{cases}1 & \text { Westbound only } \\
2 & \text { Eastbound only } \\
3 & \text { Westbound \& Eastbound }\end{cases} \\
& m= \begin{cases}0 & \text { non of the three ports } \\
1 & \text { only Singapore } \\
2 & \text { only Port Klang } \\
3 & \text { only Tanjung Pelapes } \\
4 & \text { Singapore \& Port Klang } \\
5 & \text { Singapore \& Tanjung Pelapes } \\
6 & \text { Port Klang \& Tanjung Pelapes } \\
7 & \text { all the three ports }\end{cases}
\end{aligned}
$$

For instance, if service $k$ is not an alliance member, on the Eastbound only, and calls at only Singapore port among these three ports, the notation will be $k_{0,2}^{1}$. Empirical analysis of the results shall be made using the Venn diagram depicted in Figure 1 . The triple helix distinguishes between the nature of those services identified that called at the selected ports

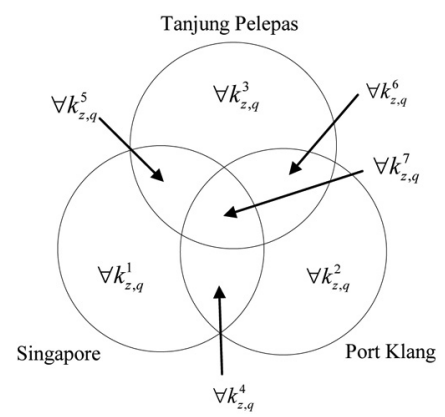


including the port-of-rotation involved in the network as well as whether these were operated by shipping alliances or otherwise.

The proposed research framework is summarized in Figure 2. The research approach considered five differentiating factors to identify those sets of relevant services. The first differentiating factor is to identify those services that are plying on the Asia-Europe trade route. These services are distinguished by their port-of-calls to include a set of ports that are located in East Asia and another set of ports that are located in Europe. Container shipping services that ply on the Asia-Europe trade would include both sets of ports in the same service loop. The second differentiating factor is to determine if those services, that have been identified to operate on the Asia-Europe trade route, have been called at either of the three ports specified in our research. This step is necessary, as there could be shipping services that bypass all of the three ports for the trade route. Our interest is to identify those shipping services that are calling either at Singapore, Port Klang or Tanjung Pelepas. Having identified the relevant data set for the analysis, the third step is to determine the nature of service calls made. These are differentiated by those that consist of exclusive calls, which is for $m=1,2$ or 3 or those that consist of parallel calls made at two or more of the selected ports where $m=4,5,6$ or 7 . Analysis into the nature of the port call is important for revealing the dynamics of relationships between the three selected ports. Calls that were made solely at one port and not at any of the other two ports in relation to the shipping network operated by the carrier or members of a shipping alliance could be an indication of hub status for the former. In the case for parallel calls, ports which are included in the portof-rotation would indicate higher priority in the service network. This information can be obtained by analyzing the ports of rotation for each service.

Having determined the nature of the service call, the fourth differentiating factor is to distinguish whether calls were made on an eastbound journey or a westbound journey or

\section{Liner shipping alliances}

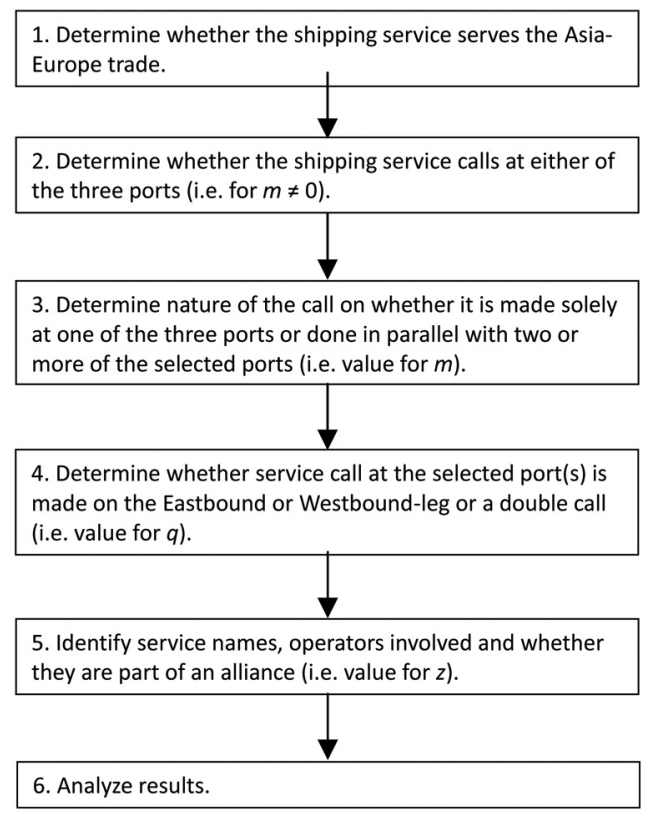

Figure 2.

Framework to identify the nature of shipping services calling at Singapore, Port Klang and Tanjung Pelepas on the Asia-Europe trade route 
MABR

3,3

248

Figure 3.

Shipping connectivity by liner services for Singapore, Port Klang and Tanjung Pelepas (2013 and 2017)

being made on both the head haul and back haul legs of the service. Head haul traffic would involve calls made on a westbound voyage (i.e. Asia-Europe) whereas eastbound voyages (i.e. Europe-Asia) would indicate back haul traffic in view of the location of the three container ports with respect to the flow of international trade on the route trade. Looking within the trade, the focus is on the head haul traffic which totaled 15.5 million TEUs in 2017 (UNCTAD, 2017, p. 12). This volume is twice that of the back haul traffic on the eastbound voyage at 7.6 million TEUs. Hence, a port which receives calls for only the westbound voyage could indicate higher priority in the shipping service network compared to a port which receives calls for only the eastbound voyage. Calls that were made on both legs of the service loop are denoted by $q$ taking the value of " 3 " and could likely indicate hub status for the port with respect to the organization of the line's shipping network. Names of the shipping services and shipping lines involved can be determined in the subsequent step. The services can also be differentiated into those that are operated as part of an alliance network which is denoted by $z$ taking the value of " 1 " as opposed to those services that are operated independent of alliances which is denoted by $z$ taking value of " 0 ". The results are analyzed in the final step which takes into consideration the characteristics of the shipping services identified in the research. Information for container shipping services was sourced from Containerisation International Yearbook 2013 (Informa plc, 2013) and Alphaliner (2017b). The analysis focused on the period lasting from year 2013 to 2017 to capture the recent developments that took place in the liner shipping industry with respect to alliance reshuffles and mergers and acquisitions.

\section{Findings and implications}

\subsection{Discussion of findings}

The results were organized into two time periods namely year 2013 which preceded the latest round of merger and acquisition and alliance reshuffle activity and 2017 which represents the more recent situation for the liner industry. Results for our analysis are shown in Figure 3.

\section{3}

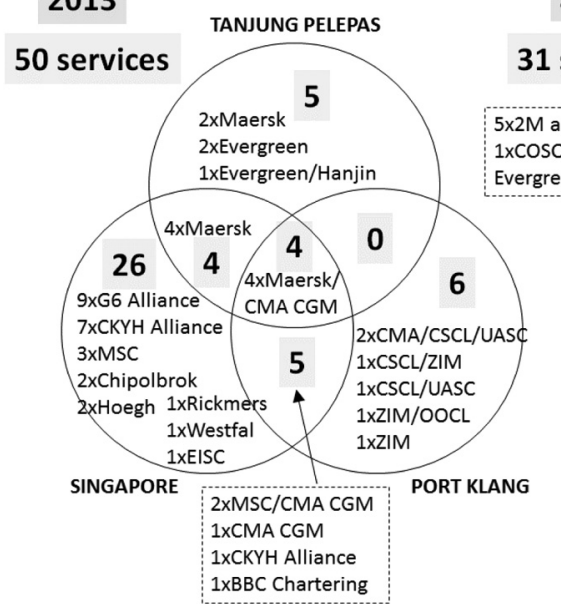

Source: Authors' computation

\section{7}

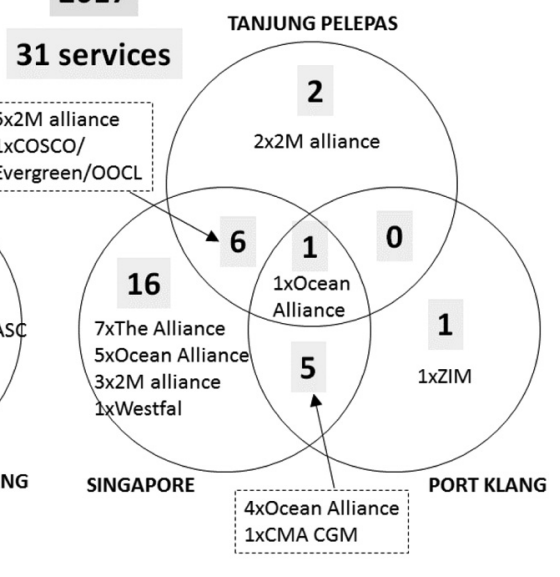


The situation in year 2013 recorded 50 shipping services on the Asia-Europe trade route that called at either of the three ports. Of these services, 26 were made solely at the port of Singapore. These consisted mostly of services operated by the G6 Alliance, CKYH Alliance alliances and container shipping line MSC. It is worth noting that majority of these services involved Singapore on both the head haul and back haul legs in their port of rotation. Our analysis also found that dedicated calls made solely at either Port Klang or Tanjung Pelepas totaled 11. Those services that called at Port Klang were made mostly by the shipping lines of CMA CGM, China Shipping, UASC and ZIM. As for Tanjung Pelepas, most of the services were operated by Maersk and Evergreen. This development could be traced back to the early 2000s where Maersk, Evergreen, CMA CGM and China Shipping made the move to relocate their hubs in Southeast Asia from Singapore to Tanjung Pelepas (Yap and Notteboom, 2011). The rest of services that called in the region contained 13 services which consisted of parallel calls comprising a combination of at least two of the three ports. Most of these shipping services involved the shipping lines Maersk and CMA CGM. Even though their hubs in the region were respectively at Tanjung Pelepas and Port Klang, both shipping lines chose to deploy a significant proportion of their services to include Singapore in the call. Similarly, MSC while choosing Singapore as their hub in Southeast Asia, deployed two services which jointly operated with CMA CGM to make parallel calls involving Port Klang. Analysis of calls made by shipping alliances found that there were nine services operated by the G6 Alliance and eight by the CKYH Alliance. It is also significant to note that almost all of these services called solely at the port of Singapore. The exception was the Asia-Black Sea Express service which was operated by the CKYH Alliance that made parallel calls at both Singapore and Port Klang.

By 2017, the situation had altered considerably with a new set of shipping alliances in place as well as exiting of long-time major industry players like Hanjin Shipping, China Shipping, APL and UASC which were either went bankrupt or acquired or merged with another shipping line. In the reorganized shipping network, the number of shipping services that called at the three selected ports was significantly reduced to 31 . Singapore continued to be the main port of call receiving dedicated calls from 16 shipping services of which 15 were operated by shipping alliances. More significantly, most of these services called at Singapore on both head haul and return legs of the voyage. These included the cargo-heavy westbound legs. By comparison, the number of dedicated services that called at either Port Klang or Tanjung Pelepas was significantly reduced from 11 such services in 2013 to three in 2017. The number of services which made parallel calls involving a combination of at least two of the three ports remained at almost the same number as seen in 2013. However, the new shipping landscape saw the dynamics of network design change to one where Singapore was paired either with Tanjung Pelepas or Port Klang. This could be attributed to the new 2M and Ocean alliances. In the case for the 2M Alliance, the Southeast Asia hub for member shipping lines Maersk and MSC is at Tanjung Pelepas and Singapore, respectively. Hence, the port of Tanjung Pelepas now included calls by MSC in addition to Maersk as the latter's sister company APM Terminals had a 30 per cent stake in the port since 2000 (Pelabuhan Tanjung Pelepas, 2000). In the case for the Ocean Alliance, Port Klang saw the continuation of calls by CMA CGM and China Shipping (now in the form of COSCO in the merged entity). However as with Tanjung Pelepas, many of these services which used to call solely at Port Klang now include joint calls made at the port of Singapore.

\subsection{Discussion of implications}

The results have four important implications from the managerial and policy perspectives. First, the results showed significant rationalization of services that called at the three ports 
MABR

3,3

250

on the Asia-Europe trade although Singapore remained the dominant port of call after the series of mergers and acquisitions and reshuffle in alliance membership. We also observed that the number of vessels involved in the trade fell from 397 in 2013 to 262 in 2017 . The behavior of shipping lines in the new operating landscape suggested that there was significant overcapacity in terms of the number of shipping services provided which necessitated rationalization of shipping networks. Should overcapacity persist, terminal operators and port authorities should be cognizant that there could be further rationalization, as shipping lines continue to streamline their service networks in the postmerger and acquisition environment. Specifically, emphasis on commercial bottom lines and pursuit of operational efficiencies could see shipping lines rationalize their networks further with consequences on hubbing strategies followed by the respective shipping alliances. For example, China Shipping used to call only at Port Klang prior to its merger with COSCO. However in the post-merger environment, service rationalization of the merged entity changed from making dedicated calls at Port Klang to now include the port of Singapore. A similar situation was observed for Evergreen which moved away from making dedicated calls at Tanjung Pelepas to now include the port of Singapore. As such, while Singapore continued to be the only major container transshipment hub in the region to receive calls by members of all the three shipping alliances and the Ocean Alliance and 2M alliance continued to call respectively at Port Klang and Tanjung Pelepas, the scenario could be affected by overcapacity in shipping, pending developments in world trade. With reference to Table II, each of the alliances are anchored by a few key players. These are Maersk and MSC for the 2M alliance, CMA CGM and COSCO for the Ocean Alliance and Hapag-Lloyd for The Alliance. Nonetheless, the disparity in fleet capacity and membership composition between the three alliances suggests that the situation is unlikely to remain stable. This could result in another round of merger and acquisition and potential reshuffle in the near term. Specifically, The Alliance was found to lag behind the two leading shipping alliances not only in terms of fleet capacity but also in potentially higher coordination costs with more member lines involved even though Hapag-Lloyd is the largest single contributor by ship capacity. The potential instability could see specific shipping lines in The Alliance being acquired by members of the two leading alliances which results in the container shipping industry being dominated by two mega alliances with each commanding almost 10 million TEUs in shipping capacity. Hence, the evolving situation could necessitate further concentration of service calls in one or two locations in Southeast Asia that offer the best financials and economics especially for those shipping lines who are key drivers behind each of the alliances.

Second, the results appeared to suggest that participation in alliance arrangement is an important strategy for shipping lines to compete successfully on the Asia-Europe trade

Table II.

Composition of $2 \mathrm{M}$

Alliance,

Ocean Alliance and The Alliance by fleet capacity as of

September 2017

\begin{tabular}{lll}
\hline 2M Alliance & Ocean Alliance & The Alliance \\
\hline Maersk $(57 \%)$ & CMA CGM $(42 \%)$ & Hapag-Lloyd (43\%) \\
MSC $(43 \%)$ & COSCO and OOCL (41\%) & Yang Ming $(16 \%)$ \\
& Evergreen $(17 \%)$ & MOL $(16 \%)$ \\
& NYK $(15 \%)$ \\
Total fleet capacity & K Line $(10 \%)$ \\
7.3 million TEUs & Total fleet capacity & Total fleet capacity \\
& 6.1 million TEUs & 3.6 million TEUs
\end{tabular}

Source: Authors, compiled using data from Alphaliner (2017a) 
route. The new shipping landscape in 2017 showed that most of the services were operated in the form of shipping alliances with 10 services operated each by the $2 \mathrm{M}$ alliance and Ocean Alliance and seven services operated by The Alliance. If we included the two services Liner shipping alliances which are operated by CMA CGM and the joint consortium of COSCO, Evergreen and OOCL who are all members of the Ocean Alliance, total number of shipping services related to members of the Ocean Alliance would increase further from 10 to 12 . By contrast, the situation in 2013 saw shipping services operated under the G6 Alliance or CKYH Alliance to be in the minority. Analysis of the three shipping alliances revealed distinct calling patterns in their network arrangement. Members of The Alliance were found to call solely at the port of Singapore. The development represents the continuation of calling arrangements by member lines Hapag-Lloyd, K Line, MOL, NYK, UASC and Yang Ming while they were members of the G6 Alliance and CKYH Alliance. Analysis of shipping services operated by the Ocean Alliance found the entity to put greater emphasis on Singapore with many of their services calling at the port on both legs of the voyage or the westbound leg. By contrast, many of those services operated by the $2 \mathrm{M}$ alliance tended to put greater emphasis on Tanjung Pelepas by calling at the port on the westbound leg and Singapore on the return voyage from Europe to Asia. As a whole, evidence from the revised shipping landscape seemed to show alliance strategy as the way forward for container shipping lines to survive on the intensely competitive Asia-Europe trade route.

Third, dynamics in the new state of port competition in Southeast Asia suggest the need to cater to the needs of the alliance and associated subsidiary regional and feeder lines as opposed to the strategy of anchoring specific shipping lines. Terminal operators and port authorities in the three ports had been focusing on enticing major shipping lines to hub transshipment operations in their respective facilities. This strategy was complemented by efforts to target specific services to boost connectivity to particular regions. These initiatives were supported by a slew of arrangements including joint venture terminals and other forms of preference treatments such as priority berthing and special rates. While these initiatives continue to remain relevant in the new setting, target clientele would have to be extended beyond the key anchor shipping line of the alliance to other members. For example, in the era of the 2M Alliance, PSA in Singapore would need to cater to the operational and commercial requirements not only of MSC but also of Maersk who is also a key member of the shipping alliance. Similarly, terminal operator Westports Malaysia in Port Klang would need to cater to the needs not only of CMA CGM but also to the requirements of COSCO and Evergreen where all three are members of the Ocean Alliance. This involves anticipating and meeting the complexities posed by an expanded shipping network and vessel fleet as well as the dynamics of intra-alliance relationships. Hence, the port that is able to contribute most toward fulfilling the demands of the alliance will emerge as the preferred hub of choice in Southeast Asia.

Fourth, the industry has entered into an era of mega alliances which requires commensurate responses in terms of handling capacity from the port and terminal perspective. This will include aspects covering terminal design, handling technology, channel approach, fairways and anchorages, port draft and terminal capacity among other concerns. With reference to Table III, we note the number of shipping services deployed as part of alliances form the majority in 2017. The number of vessels operated in alliances also rose from 171 to 226 from 2013 to 2017. By contrast, non-alliance shipping services fell from 33 to four and the number of vessels involved also dropped from 226 to 36 in the same time period. We note from the analysis that average vessel size along the Asia-Europe trade route rose considerably by 52 per cent from 9,143 TEUs in 2013 to 13,943 TEUs in 2017. This was attributed to the fact that the trade continued to receive the largest container 


\section{MABR \\ 3,3}

\section{2}

Fleet attributes

Contestability

Number of shipping services

Part of alliance

Non-alliance

Number of vessels

Part of alliance

Non-alliance

Terminal investment

Size of the largest vessel

Operator

Vessel length overall

Vessel breadth

Table III.

Fleet deployment on Asia-Europe trade for Singapore, Port Klang and Tanjung Pelepas

\section{Vessel draft}

Capacity development

Average vessel capacity

Total fleet capacity for the trade
2013

50

17

33

397

171

226

18,270 TEUs

Maersk Line

399 meters

59 meters

16.0 meters

9,143 TEUs

$3,630,000$ TEUs
2017

$(\%)$ change

Sources: various, including authors', computation using data from Alphaliner (2017b)

vessels, reaching 20,568 TEUs in 2017. The latest of these vessels were deployed in the 2M Alliance. In terms of vessel dimension, these behemoths require drafts of up to 16.5 meters. As such, ports and terminals that strive for hub status have to provide sufficient capabilities in terms of infrastructure, software and human resource to handle these mega container ships. In addition, associated with the mega alliances are their shipping networks and larger container volumes which must be accommodated without compromising the efficient functioning of the alliance as well as the entire port. It is important to note that container handling is just one aspect of the port business. There is competing usage demand from other sectors in the port industry which include non-containerized cargo as well as ship-related ancillary services. These activities are typically located in the same vicinity thereby increasing pressure on space utilization from the landward and seaward perspectives. This might necessitate redesign and relocation of new container handling facilities in new sites to capitalize on the latest advances and frontiers of new technology to accommodate the abovementioned developments.

\section{Conclusion and recommendations for future research}

This is the first research effort to consider the impact from the recent round of alliance reshuffle which comprised a series of events that took place from year 2014 to 2017. In place of the G6 Alliance and CHKYE Alliance are three new shipping alliances which are the 2M Alliance, Ocean Alliance and The Alliance. The research methodology uses information for shipping services that are deployed on the Asia-Europe trade route and focused on the three major container transshipment hubs in Southeast Asia which are Singapore, Port Klang and Tanjung Pelepas. Results from the shipping scene in 2017 revealed that Singapore continued to be the main port of call. However, the number of dedicated calls at Port Klang and Tanjung Pelepas was significantly reduced. The dynamics of network design was also changed to one where Singapore was paired either with Tanjung Pelepas or Port Klang.

The research highlighted four implications from the managerial and policy perspectives. First, there was significant rationalization of shipping capacity. Should overcapacity persist, emphasis on commercial bottom lines and pursuit of operational efficiencies could see 
further rationalization. This development could be aided by structural instabilities especially for The Alliance which lagged considerably behind the 2M and Ocean Alliance in terms of fleet capacity and potentially higher coordination costs among member lines. As a result, the industry could evolve toward being dominated by two mega alliances with consequential rationalization of shipping service networks to one or two locations in Southeast Asia that offer the best financials and economics. Behavior of shipping lines in the new operating landscape also suggested that participation in an alliance arrangement could be an important strategy to compete successfully on the Asia-Europe trade route. Although majority of shipping services deployed on the Asia-Europe trade in 2013 that called at the three ports did not belong to any specific alliances, the situation in 2017 saw a reverse with 27 out of 31 services belonging to an alliance. Including two shipping services operated separately by different members of the Ocean Alliance would bring the total number of alliance-related services to 29. Hence, evidence from the research seemed to point toward alliance strategy as the way forward for container shipping lines to survive on the intensely competitive Asia-Europe trade route.

The results also revealed that terminal operators and port authorities will need to cater to the needs of the alliance and their associated subsidiary regional and feeder lines unlike the strategy of targeting specific lines or shipping service to anchor at the port. Hence, retaining the hub status would necessitate being useful especially to key members of an alliance to entrench the entities' network in the port. This is made even more critical with most shipping lines and services operating under the aegis of shipping alliances. As a result, there will be implications for port managers and terminal operators in their berth allocation policies, policies for priority berthing and even policies involving selection of partners to enter into joint ventures. In the case for Singapore, its status as a hub for Ocean Alliance was strengthened by CMA CGM jointly investing with PSA to operate four container berths with an annual capacity of 4 million TEUs at the new Pasir Panjang Terminal (Woo, 2017). CMA CGM which used to hub at Port Klang, announced its commitment to hub at Singapore with more service calls following the acquisition of APL (Woo, 2015). In addition, PSA and COSCO announced a new joint venture agreement to replace the original two berths at Pasir Panjang Terminal 1 with three larger berths at the new Pasir Panjang Terminal 5 (The Straits Times, 2017b). The three berths will have an annual capacity of 3 million TEUs. More significantly, both joint venture terminals by PSA with CMA CGM and COSCO are located at the same terminal which is Pasir Panjang Terminal 5. By doing so, PSA could better cater to the needs of two key players of the Ocean Alliance and capitalize on efficiencies afforded by terminal operations in a single location. Similarly, while Maersk continued to call at its hub in Southeast Asia which is located at Tanjung Pelepas, the carrier dedicated a significant proportion of its calls in the region to include Singapore together with its alliance partner MSC. As such, there is the need to not only cater to the needs of MSC which has a joint venture terminal in Pasir Panjang Terminal 2 but also being able to handle services that are operated by the shipping line's alliance partner Maersk. The analysis further notes that catering to the needs of mega alliances will require appropriate responses from the supply side and that the container-handling business is just one aspect the port needs to accommodate. There is competing usage demand from other sectors in the port industry. As such, the situation might necessitate redesign and relocation of containerhandling facilities to account for the abovementioned developments. As a result, there will be implications for port managers and terminal operators in their berth allocation policies, policies for priority berthing and even policies involving selection of partners to enter into joint ventures.
Liner shipping
alliances

253 
MABR

3,3

254

The research addresses the gap in literature concerning the recent alliance reshuffle and its impact on the state of shipping connectivity using the case of the Asia-Europe trade route pertaining to key transshipment hubs in Southeast Asia. Because the research approach adopted considered the supply perspective through shipping services deployed at the various ports, future research could address perspectives drawn from other key trade routes and geographical regions as well as supply chain effects to provide a comprehensive understanding on the network dynamics in the new shipping landscape.

\section{References}

Alphaliner (2013), “Top 100”, available at: www.alphaliner.com (accessed 25 October 2013).

Alphaliner (2017a), “Top 100”, available at: www.alphaliner.com (accessed 26 September 2017).

Alphaliner (2017b), “Services”, available at: www.alphaliner.com (accessed 1 December 2017).

American Association of Port Authorities (2017), "World port rankings 2015”, available at: www.aapaports.org/ (accessed 11 April 2018).

Calatayud, A., Mangan, J. and Palacin, R. (2017), “Connectivity to international markets: a multi-layered network approach", Journal of Transport Geography, Vol. 61, pp. 61-71.

Chao, S.-L. (2017), "Integrating multi-stage data envelopment analysis and a fuzzy analytical hierarchical process to evaluate the efficiency of major global liner shipping companies", Maritime Policy and Management, Vol. 44 No. 4, pp. 496-511.

Das, S.S. (2011), "To partner or to acquire? A longitudinal study of alliances in the shipping industry", Maritime Policy and Management, Vol. 38 No. 2, pp. 111-128.

Espina, K. (2016), "Newly formed the alliance seen as match for 2M and ocean alliance", available at: https://loydslist.maritimeintelligence.informa.com/ (accessed 18 April 2018).

Evangelista, P. and Morvillo, A. (1999), “Alliances in liner shipping: an instrument to gain operational efficiency or supply chain integration?", International Journal of Logistics: Research and Applications, Vol. 2 No. 1, pp. 21-38.

Ferrari, C., Parola, F. and Benacchio, M. (2008), "Network economies in liner shipping: the role of home markets", Maritime Policy and Management, Vol. 35 No. 2, pp. 127-143.

Informa plc (2013), Containerisation International Yearbook, 2013, Informa plc, London.

Knowler, G. (2016), "Merged cosco-CSCL: shipper contracts valid until new alliance launches", available at: www.joc.com/ (accessed 15 March 2018).

Lakshmi, A. (2016), “Ocean alliance vs 2M”, available at: www.marinelink.com/ (accessed 19 March 2018).

Lam, J.S.L. (2013), "Benefits and barriers of supply chain integration: empirical analysis of liner shipping”, International Journal of Shipping and Transport Logistics, Vol. 5 No. 1, pp. 13-30.

Lam, J.S.L. and Yap, W.Y. (2011), "Container port competition and complementarity in supply chain systems: evidence from the pearl river Delta", Maritime Economics and Logistics, Vol. 13 No. 2 , pp. 102-120.

Lam, J.S.L. and Yap, W.Y. (2008), “Competition for transshipment containers by major ports in Southeast Asia: slot capacity analysis”, Maritime Policy and Management, Vol. 35 No. 1, pp. 89-101.

Midoro, R. and Pitto, A. (2000), "A critical evaluation of strategic alliances in liner shipping”, Maritime Policy and Management, Vol. 27 No. 1, pp. 31-40.

Pelabuhan Tanjung Pelepas (2000), "Maersk: our stake in PTP no deterrence", available at: www.ptp. com.my/media-hub/news/ (accessed 8 May 2018).

Power, T. Mason, T. and Kapoor, R. (2016), "Consolidation in the liner industry: white paper", available at: www.drewry.co.uk/AcuCustom/Sitename/DAM/003/Drewry_WhitePaper_Liner_Industry_ Consolidation_March_2016.pdf (accessed 29 March 2018). 
Rau, P. and Spinler, S. (2017), "Alliance formation in a cooperative container shipping game: performance of a real options investment approach", Transportation Research Part E, Vol. 101, pp. 155-175.

Reuters (2016a), "Hanjin shipping files for receivership, as ports turn away its vessels", available at: https://uk.reuters.com/ (accessed 28 February 2018).

Reuters (2016b), "Hyundai merchant marine forms tie-up with 2M alliance", available at: https:/uk. reuters.com/ (accessed 28 April 2018).

Ryoo, D.-K. and Lee, T.W. (2002), "The role of liner shipping co-operation in business strategy and the impact of the financial crisis on Korean liner shipping companies", in Grammenos, C.T. (Ed.), The Handbook of Maritime Economics and Business, L.L.P., London.

Ryoo, D.-K. and Thanopoulou, H. (1999), "Liner alliances in the globalization era: a strategic tool for Asian container carriers", Maritime Policy and Management, Vol. 26 No. 4, pp. 349-367.

Saadi, D. (2017), "Hapag-Lloyd ready to expand after UASC merger", available at: www.thenational.ae/ international (accessed 1 May 2018).

Slack, B., Comtois, C. and McCalla, R. (2002), "Strategic alliances in the container shipping industry: a global perspective”, Maritime Policy and Management, Vol. 29 No. 1, pp. 65-76.

Tang, L.C., Low, J.M.W. and Lam, S.W. (2011), "Understanding port choice behavior - a network perspective”, Networks and Spatial Economics, Vol. 11 No. 1, pp. 65-82.

The Straits Times (2017a), "South Korea's once-mighty Hanjin shipping declared bankrupt”, available at: www.straitstimes.com/ (accessed 5 March 2018).

The Straits Times (2017b), "Cosco and PSA to launch new berth in S'pore", available at: www. straitstimes.com/ (accessed 5 March 2018).

UNCTAD (2017), Review of Maritime Transport 2017, United Nations Publication, Geneva.

Wackett, M. (2016), "Zim and the alliance to offer joint mediterranean-US east Coast services next year", available at: https://theloadstar.co.uk/ (accessed 29 March 2018).

Wen, Y.-H. (2012), "Impact of collaborative transportation management on logistics: capability and competitive advantage for the carrier", Transportation Journal, Vol. 51 No. 4, pp. 452-473.

Woo, J. (2015), "French shipping giant CMA CGM to reinforce Singapore's hub status", available at: www.straitstimes.com/ (accessed 15 April 2018).

Woo, J. (2017), "PSA, CMA CGM double capacity of container terminal joint venture", available at: www.straitstimes.com/ (accessed 1 May 2018).

Yang, D., Liu, M. and Shi, X. (2011), "Verifying liner shipping alliance's stability by applying core theory", Research in Transportation Economics, Vol. 32 No. 1, pp. 15-24.

Yap, W.Y. and Lam, J.S.L. (2013), "80 Million-TEU container port? Sustainability issues in port and coastal development”, Ocean and Coastal Management, Vol. 71, pp. 13-25.

Yap, W.Y. and Notteboom, T. (2011), "Dynamics of liner shipping service scheduling and their impact on container port competition", Maritime Policy and Management, Vol. 38 No. 5, pp. 471-485.

Zhong, N. (2014), "2M alliance charts ships' new course”, available at: www.chinadaily.com.cn (accessed 14 April 2018).

\section{Corresponding author}

Wei Yim Yap can be contacted at: wyyap@suss.edu.sg

\section{Liner shipping alliances}

